\title{
PENYULUHANPELATIHAN ORIENTASI KEWIRAUSAHAAN BAGI PENGRAJIN FIGURA BINGKAI KAYU JATI RIZKYMARTAPURA
}

\author{
Sulastini, Dewi Ariefahnoor dan Adhi Surya \\ Fakultas Ekonomi, Universitas Islam Kalimantan MAB \\ Email :aisyahsulastini@gmail.com
}

\begin{abstract}
Entrepreneurial activity is not the result of an inheritance or a derivative talent parents alone, entrepreneurship can be taught and nurtured. The ability to create and use new knowledge on an ongoing basis is strongly influenced by the degree of entrepreneurial person. Therefore, entrepreneurship is defined ability to create and build a vision of something that does not exist and meaningful to humans through creative action and innovative measures to create business opportunities. Entrepreneurial action is manifested as an entrepreneurial orientation is behavior that reflected the behavior of the owner or craftsman through keinovasian, dare to take risks and proactivity. Given the importance of entrepreneurial orientation training to succeed as a business then craftsmen figura teak frame Rifky in Martapura Banjar district needs to develop entrepreneurship orientation in its business activities. Motifs, colors and designs are less attractive and less innovative so that interest figura teak frame is very less. Unlike the typical Java figura in addition to easily be everywhere also available in various designs, patterns and colors. In addition to expression differences with Java figura. It is necessary for the training effort for the craftsmen in Martapura Banjar district cultivate the spirit more active and resilient in the face of all obstacles either comes from internal and external craftsmen craftsmen, so figura teak able to increase revenues for craftsmen figura teak. Internal aspects indicated the failure of the craftsman among others the quality of the resource, setting the selling price is relatively high, the motives are less developed, deterioration of working capital and the increase in debt as a result of low accumulation of capital and the inability to find sources of capital cost, network limited business, the ability to innovate are less able. This information indicates internal weaknesses that have the potential to make an effort figura teak can fail.
\end{abstract}

Keywords:Orientation Training Entrepreneurship, Constraints Internal and External of Entrepreneurship Rizky Figura, and Rizky's Craftsmen Figura Teak Martapura.

\section{PENDAHULUAN}

Kegiatan kewirausahaan bukanlah hasil

warisan atau bakat turunan orang tua

semata, kewirausahaan juga dapat

diajarkan dan ditumbuhkan.

Kemampuan menciptakan dan

menggunakan pengetahuan baru secara berkesinambungan sangat dipengaruhi

oleh derajad kewirausahaan

seseorang.Oleh karena itu

kewirausahaan didefinisikan

kemampuan untuk menciptakan dan membangun suatu visi dari sesuatu yang tidak ada menjadi ada dan bermakna 
bagi manusia melalui tindakan kreatif dan tindakan inovatif untuk terciptanya peluang bisnis.Tindakan kewirausahaan ini diwujudkan sebagai orientasi kewirausahaan yaitu perilaku yang tercermin dari perilaku pemilik atau pengrajin melalui keinovasian, berani mengambil resiko dan proaktivitas. Mengingat pentingnya pelatihan orientasi kewirausahaan dalam meraih kesuksesan usaha, maka pengrajin bingkai kayu jati di Martapura Kabupaten Banjar perlu mengembangkan orientasi kewirausahaan dalam aktivitas-aktivitas usahanya. Karena figura bingkai kayu jati merupakan salah satu hasil kebudayaan masyarakat Kalimantan Selatan yang diwariskan secara turuntemurun.Dan bingkai kayu jati merupakan salah satu sektor yang cukup berpengaruh terhadap perekonomian provinsi Kalimantan Selatan, sangat berpotensi menciptakan lapangan kerja yang cukup besar khususnya bagi pengrajin figura bingkai kayu jati di Martapura.Namun kenyataannya figura bingkai kayu jati belum mendapatkan tempat di hati masyarakat Martapura secara luas.Hal ini terjadi karena figura bingkai kayu jati belum menyentuh seluruh lapisan masyarakat secara luas, selain bentuk figura bingkai kayu jati dan kurang inovatif, sehingga masyarakat enggan menggunakannya. Selain motif, warna dan desain kurang menarik dan kurang inovatif sehingga minat terhadap figura bingkai kayu jati sangat kurang. Berbeda dengan figura khas Jawa yang selain mudah di dapat dimana-mana juga tersedia dalam berbagai desain, motif dan warna.Selain ungkapan perbedaan dengan figura Jawa.Untuk itu perlu dilakukan upaya pelatihan bagi pengrajin di Martapura Kabupaten Banjar menumbuhkan semangat lebih giat dan tangguh dalam menghadapi segala kendala-kendala baik berasal dari internal pengrajin maupun eksternal pengrajin, sehingga figura kayu jati mampu meningkatkan pendapatan bagi para pengrajin figura kayu jati. Dalam kegiatan pengabdian ini lebih kepada penyuluhan orientasi kewirausahaan ditinjau dari aspek-aspek internal yang diindikasikan mempengaruhi kegagalan pengrajin antara lain kualitas sumberdaya, penetapan harga jual yang relatif tinggi, motif yang kurang berkembang, kemerosotan modal kerja dan meningkatnya hutang sebagai akibat rendahnya akumulasi modal dan ketidak mampuan mencari sumber-sumber 
permodalan yang murah, jaringan usaha yang terbatas, kemampuan untuk melakukan inovasi yang kurang bisa menjual. Informasi ini menunjukkan kelemahan internal yang berpotensi membuat suatu usaha figura kayu jati bisa gagal.

\section{KHALAYAK SASARAN}

\section{Peserta Kegiatan}

Kegiatan Pengabdian kepada masyarakat ini diikuti oleh pengrajin figura rizky di Martapura Kabupaten Banjar dan dosen dan mahasiswa Fakultas Ekonomi Universitas Islam Kalimantan MAAB Banjarmasin. Jadwal kegiatan Pengabdian Kepada Masyarakat ini sebagai berikut :

\begin{tabular}{|c|l|c|c|c|}
\hline \multirow{2}{*}{ No } & \multicolumn{2}{|c|}{ Uraian Kegiatan } & \multicolumn{2}{|c|}{$\begin{array}{c}\text { Kegiat } \\
\text { an }\end{array}$} \\
\cline { 3 - 5 } & \multicolumn{1}{|c|}{$\begin{array}{l}\text { Membuat surat menyurat } \\
\text { kepada Pengrajin Figura } \\
\text { Rizky di Martapura. }\end{array}$} & $\mathbf{X}$ & & \\
\hline 2 & $\begin{array}{l}\text { Mengirim Undangan ke } \\
\text { peserta Pengrajin Figura } \\
\text { Rizky di Martapura }\end{array}$ & $\mathbf{X}$ & & \\
\hline 3 & Pelaksanaan Pelatihan & & $\mathbf{X}$ & \\
\hline 4 & $\begin{array}{l}\text { Pembuatan Resume Hasil } \\
\text { Pengabdian Masyarakat }\end{array}$ & $\mathbf{X}$ & \\
\hline 5 & $\begin{array}{l}\text { Pembuatan laporan hasil } \\
\text { kegiatan pelatihan }\end{array}$ & & $\mathbf{X}$ \\
\hline
\end{tabular}

\section{METODE}

Metode pendekatan yang disampaikan berupa penyuluhan pelatihan dan diskusi. Metode penyuluhan bertujuan untuk memberikan wawasan pengetahuan kepada para pengrajin tentang orientasi kewirausahaan. Bahwa sebagai pengrajin tidak hanya memiliki suatu gaya yang kreatif dan inovatif, namun juga memiliki keahlian manajemen dan pengetahuan bisnis yang solid. Proses kreatif dan inovatif hanya dilakukan oleh individu yang memiliki kepribadian kreatif dan inovatif yaitu orang yang memiliki jiwa, sikap, dan perilaku kewirausahaan dengan ciri-ciri: (1) penuh percaya diri, (2) memiliki inisiatif, (3) memiliki motif berprestasi, (4) memiliki jiwa kepemimpinan dan (5) berani mengambil resiko dengan perhitungan. Berdasarkan ciri-ciri tersebut dapat disimpulkan definisi wirausaha (entrepreneur) adalah mereka yang melakukan upaya-upaya kreatif dan inovatif dengan jalan mengembangkan ide dan meramu sumberdaya untuk menemukan peluang dan perbaikan hidup. Kemudian metode diskusi dilakukan untuk mengetahui permasalahan yang dihadapi para pengrajin di lapangan sebagai pelaku/pengrajin mulai dari ide-ide kreatif corak sampai dengan terjualnya hasil karyanya.

\section{Pelaksanaan Pelatihan}


Dalam upaya memberikan pemahaman perlunya pelatihan orientasi kewirausahaan para pengrajin figura Rizky bingkai kayu jati di Martapura dengan data sebagai berikut :

\begin{tabular}{|c|l|l|}
\hline No & \multicolumn{1}{|c|}{ Uraian } & \multicolumn{1}{|c|}{ Keterangan } \\
\hline 1. & $\begin{array}{l}\text { Nama } \\
\text { kegiatan }\end{array}$ & $\begin{array}{l}\text { Penyuluhan } \\
\text { Pelatihan Orientasi } \\
\text { Kewirausahaan } \\
\text { Bagi Pengrajin } \\
\text { Figura Bingkai } \\
\text { Kayu Jati di } \\
\text { Martapura }\end{array}$ \\
\hline 2. & $\begin{array}{l}\text { Tanggal } \\
\text { kegiatan }\end{array}$ & 30 Mei 2016 \\
\hline 3. & $\begin{array}{l}\text { Waktu } \\
\text { kegiatan }\end{array}$ & $\begin{array}{l}\text { 08.00 s.d 14.00 wita } \\
\text { Galeri Figura RIzky } \\
\text { Martapura Kayu Jati di }\end{array}$ \\
\hline 4. & Tempat & $\begin{array}{l}\text { Pengrajin Figura } \\
\text { Rizky Sebanyak 5 } \\
\text { orang }\end{array}$ \\
\hline 5. & Peserta \\
\hline
\end{tabular}

\section{HASIL DAN PEMBAHASAN}

\section{Hasil}

Setelah mengikuti kegiatan penyuluhan, pelatihan dan diskusi, hasil yang diperoleh diantaranya :

- Para pengrajin sebagian besar ibu-ibu sangat mensupport kedatangan kami sebagai penyuluh dalam kegiatan pengabdian masyarakat, hal ini terbukti para pengrajin tepat waktu hadir dan mengisi tempat duduk di ruangan yang telah disediakan.
- Para pengrajin menyimak dengan tekun dan serius serta mendengarkan materi penyuluhan tanpa ada seorangpun yang meninggalkan ruangan sebelum kegiatan berakhir. Sesi diskusi/tanya jawab juga berlangsung dengan baik dan memuaskan.

- Para pengrajin menyadari dan memahami bahwa pengrajin senantiasa memikirkan pertumbuhan usahanya tidak hanya memiliki suatu gaya yang kreatif dan inovatif, namun juga memiliki keahlian manajemen dan pengetahuan bisnis. Proses kreatif dan inovatif hanya dilakukan oleh individu yang memiliki kepribadian kreatif dan inovatif yaitu orang yang memiliki jiwa, sikap, dan perilaku kewirausahaan.

\section{Pembahasan}

Pembelajaran kewirausahaan sangat diperlukan pelatihan kembali bagi para pengrajin, agar supaya memahami cara memanfaatkan kemampuan dirinya secara optimal guna dapat menangkap peluang-peluang yang selalu terjadi setiap saat serta dapat melaksanakan kegiatan secara mandiri. 
Pengrajin harus memiliki pengetahuan dan kemampuan melakukan kegiatan atau usaha secara mandiri dan dapat memanfaatkan perubahan-perubahan situasi lingkungan kehidupan atau bisnis yang cepat berubah.

Pengrajin yang memiliki jiwa wirausaha yang andal, dibutuhkan karakter seperti pengenalan terhadap diri sendiri (self awareness), kreatif, mampu berpikir kritis, mampu memecahkan permasalahan (problem solving), dapat berkomunikasi, mampu membawa diri di berbagai lingkungan, menghargai waktu, empati, mau berbagi dengan orang lain, mampu mengatasi stress, dapat mengendalikan emosi dan mampu membuat keputusan. Kewirausahaan juga identik dengan mengambil resiko, menciptakan hal-hal yang baru baik produk, proses atau cara pandang baru, serta melihat peluang yang belum diketahui oleh orang lain.

Kewirausahaan lebih soal menggerakkan perubahan mental dan tidak perlu dipertentangkan bahwa kewirausahaan itu sesuatu yang dapat dipelajari atau didapatkan sebagai bakat genetis. Pada dasarnya apa yang disebut bakat sebetulnya dapat saja merupakan pengaruh lingkungan dan hasil pembelajaran atau pendidikan.
Kewirausahaan juga diawali dengan sikap (attitude) yaitu sikap untuk bekerja menjadi wirausaha lebih merupakan cara pandang, pikir dan sikap bahwa semua hal dapat dipelajari. Dengan demikian dapat dikatakan bahwa jiwa kewirausahaan dapat dibangun melalui pembelajaran atau pendidikan. Media yang digunakan untuk membangun jiwa kewirausahaan, adalah (1) pendidikan/pelatihan, (2) seminar/diskusi serta (3) magang dan praktek kerja.

\section{FOTO KEGIATAN}

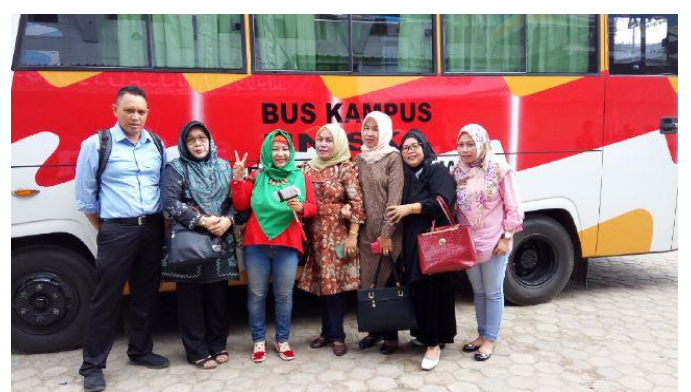

Tim PelaksanaPengabdian pada

Masyarakat yang dipimpin

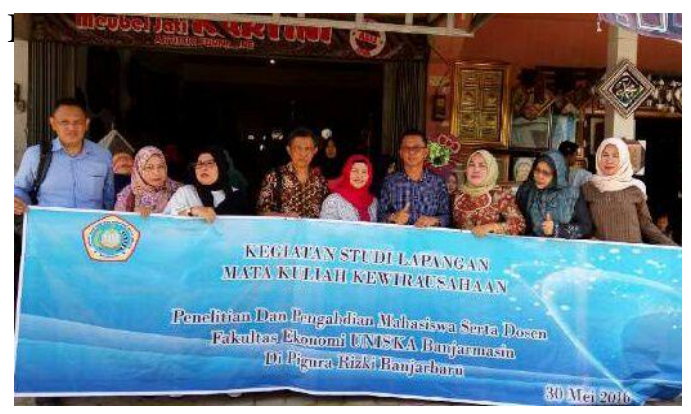

Tim Pelaksana bersama mahasiswa dan dosen Fakultas Ekonomi. 


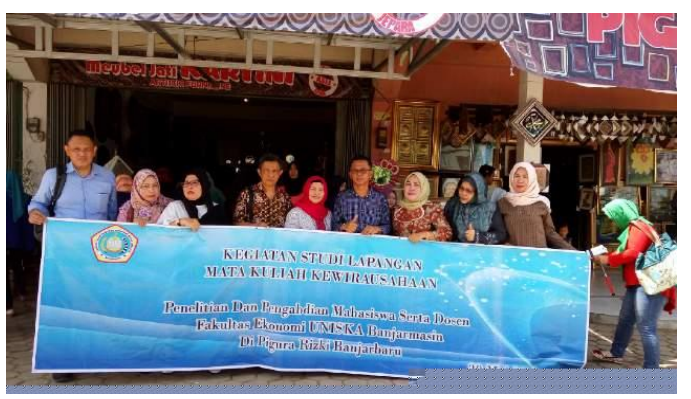

Tim Pelaksana bersama mahasiswa dan dosen Fakultas Ekonomi.

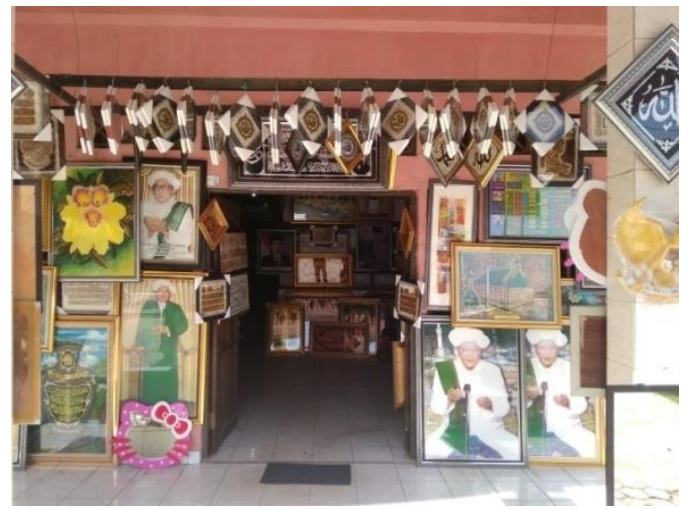

Produksi Figura Rizky Kayu Jati

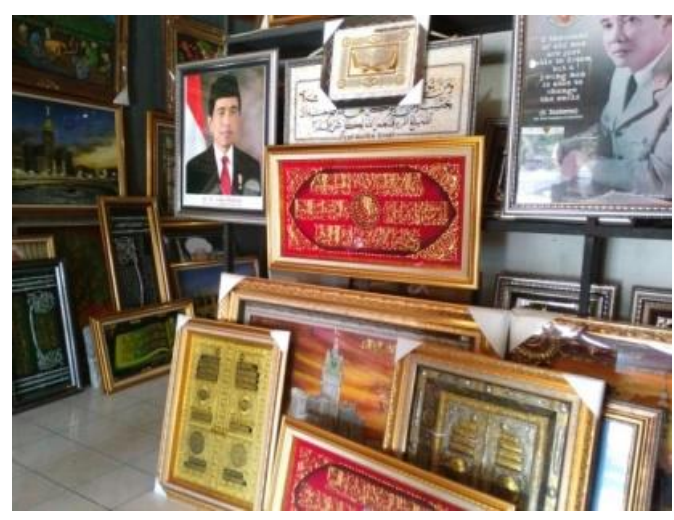

Figura Rizky Kayu Jati

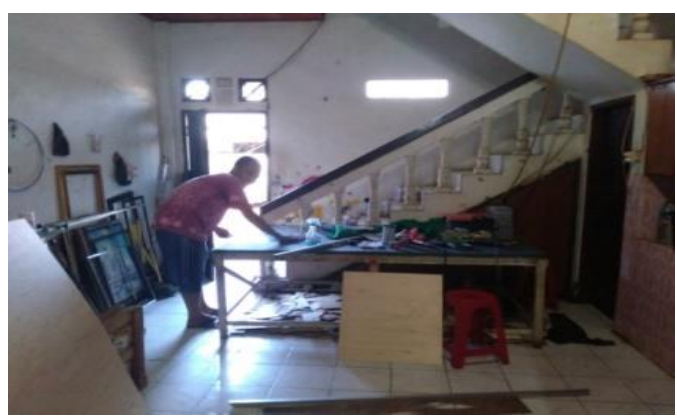

Dapur Produksi Figura Rizky

Martapura

\section{KESIMPULAN}

Berdasarkan uraian sebelumnya dan kegiatan penyuluhan pelatihan dan diskusi yang dilakukan kepada para pengrajin bahwa kewirausahaan bukanlah hasil warisan atau bakat turunan orang tua semata, kewirausahaan juga dapat diajarkan dan ditumbuhkan.Kegiatan pengabdian di masa yang akan datang perlu dipikirkan memberikan penyuluhan/penyampaian materi yang lain, yang tidak kalah bermanfaat bagi pengrajin figura di Martapura. Selain bagi penyuluh/dosen yang melakukan pengabdian dapat memberikan pengalaman dan berbagi pengetahuan juga merupakan suatu suasana yang menyenangkan dapat berinteraksi dengan profesi lain khususnya para bagi pengrajin figura di Martapura.

\section{DAFTAR PUSTAKA}

Arjamudin, 2009, Makalah Ilmu Komunikasi Hambatanhambatan Komunikasi, Jurusan Public Relationship Fakultas Ushuluddin Sulthan Thaha Saifuddin, Jambi

Hardjana, Agus, 2003, Komunikasi Intrapersonal dan Interpersonal, Kanisius, Yogyakarta Lunandi, A.G., 1994, Komunikasi Mengenai : Meningkatkan Efektifitas Komunikasi 
Interpersonal, Kanisius, Yogyakarta

Morrisandan Andy Corry Wardhany, 2009, Teori Komunikasi, Ghalia Indonesia, Bogor
Mulyana, Deddy, 2007, Ilmu

Komunikasi Suatu Pengantar, PT. Remaja Rosdakarya 